\title{
THE PERSONAL DIMENSION OF PROFESSIONAL RESPONSIBILITY
}

\author{
JOHN MIXON" AND ROBERT P. SCHUWERK"*
}

INTRODUCTION

What happens when two professors of a Keck-sponsored experimental course in personal and professional responsibility ${ }^{1}$ borrow ideas from $W$. Edwards Deming's "Continuous Quality Improvement" theory, ${ }^{2}$ Peter Senge's business systems theory, ${ }^{3}$ Scott Peck's community-building techniques, ${ }^{4}$ Andrew Watson's pungent criticisms of traditional legal education pedagogy, ${ }_{7}^{5}$ MyersBriggs personality typing, ${ }^{6}$ Donald Williamson's family systems theory, ${ }^{7}$ and oldtime story-telling? ${ }^{8}$

One University of Houston Law Center student assessed such a course offered in the spring of 1995 as "the most informative, the most communal, and the most valuable class I have experienced while in law school." Another said, "After listening and learning this semester ..., I know that I am capable of facing clients and handling their problems. I am capable of being a counselor in the true sense of the word. I can listen, care, and resolve." From another: "the most important realization that I have gained from this class-a fountainhead for all other ethics rules-[is] that I have a better understanding of myself. More simply, by looking inward I will learn to act in an ethical way outward." "Psychobabble," said the most critical student, but then added,

Copyright $\odot 1996$ by Law and Contemporary Problems

* Law Alumni Professor, University of Houston.

** Professor of Law, University of Houston.

1. This course is only one aspect of a much broader Keck-sponsored review and revision of the Law Center's curriculum. Other matters under consideration include creating a novel first-year lawyering process course focused on ethical rather than substantive or procedural issues, devising and implementing a coordinated lawyering skills curriculum for second-and third-year students, including new professional responsibility offerings, instituting a variety of pro bono and public interest programs, and supporting a variety of initiative furthering the interests of minorities and women.

2. W. EDWARDS DEMING, OUT OF THE CRISIS (1986).

3. Peter Senge, the fifth Discipline: the Art and Practice of the learning ORGANIZATION (1990).

4. M. Scott Peck, The Different Drum: Community-Making and Peace (1987).

5. Andrew S. Watson, The Quest for Professional Competence: Psychological Aspects of Legal Education, 37 U. CIN. L. REV. 91 (1968).

6. For a description of Myers-Briggs applied to law, see Larry Richard, The Lawyer Types, 79 A.B.A. J. 74 (1979). 28.

7. See Donald Williamson, The Family's Bloodless [R]evolution, Networker, May-June 1983, at

8. Our effort should not be confused with the narrative approach to legal scholarship. 
what I value most from this class was gaining the insight and wisdom of my fellow classmates. I found out what they thought on controversial issues, and how they viewed the legal profession. Sometimes I agreed, but most of the time I did not. This, however, was not important. What is important is that we had and maintained dialog.

These anonymous student comments are typical assessments of the experimental course that student evaluations placed in the top 5 percent of all law classes offered that semester, instead of the bottom 5 percent where the regular ethics course had sat for years-a commentary on students' grudging perception of the graduation requirement. Overwhelmingly, students said the experimental course should become a regular part of the curriculum, perhaps even required early in the law school experience. ${ }^{9}$

A skeptic could ascribe the favorable tone to non-competitive grading that produced a high class curve, guest speakers telling stories in lieu of reading assignments, and fun as a class goal. Maybe it was the Hawthorne effect: it doesn't matter what management does; if workers (or students) think somebody cares about them, they respond favorably. ${ }^{10}$ Yet, if one dares to take the student comments at face value, something worked. Something caused these students to become excited about joining a profession that has received more brickbats than bouquets in recent years.

The development of the course is difficult to describe. In order to do so in this essay, we ${ }^{11}$ first offer our views on what is wrong with the traditional approach to law of lawyering or professional responsibility courses. Next we set out our views of the general parameters of a better approach and offer a nutshell of what we did. We continue with an explanation of the underlying theories that guided us, integrated with a more detailed presentation of related features of the course. We conclude with an evaluation of our experience and a critique of that effort.

The TRaditional Versus the IMPRoved Professional ResPonsibility COURSE

A. What's Wrong with the "Traditional" Professional Responsibility Course?

We realize the risk in even speaking of the "traditional" professional responsibility or "law of lawyering" course. Experimental pedagogical

9. A more sobering reality is that simply repeating the course has required some strong advocacy before both our curriculum committee and an administration that fought against any erosion of the course curve requirement.

10. "After the 1930s Western Electric experiments which inadvertently demonstrated that productivity increased when a work situation was constantly attended to and stimulated, regardless of the precise type of intervention-lights up, productivity up; lights down, productivity up again." Thomas J. Peters, Thriving on ChaOs 94 (1987).

11. When necessary to distinguish who did what, we refer to ourselves by individual name. 
techniques are used in conjunction with those offerings far more than with any other subject. In addition to employing the traditional Socratic method in conjunction with casebooks (which themselves come in a far wider variety of formats and emphases than is true in other disciplines), we are aware of courses-some free-standing, others integrated with other relevant offerings such as Trial Advocacy and Evidence-based on simulations, storytelling, problems, guest speakers, movies, and audio-visual vignettes. Those approaches, and in all likelihood many others we have not heard of, are utilized in a bewildering variety of combinations in an effort to convey the underlying material to students in a way that impresses them with its importance to their lives as lawyers.

Despite such efforts, generally students are not impressed. ${ }^{12}$ In many schools, such courses traditionally receive much lower student evaluations than those earned in other substantive courses. For our school at least, this is true no matter who teaches the course, what methods they employ, and what evaluations the professors receive in their other subjects. Upon reflection, this is a bizarre situation. Something is going on when so many innovative pedagogical techniques applied to such intrinsically interesting and universally relevant subject matter generate such an unenthusiastic response.

We believe we know what that "something" is. It is the fundamental clash between the detached, analytical, and reified values promoted by the traditional "Socratic" method of legal instruction and the "me first," lone-wolf mentality generated by the forced grading curve on the one hand, and the engaged, contextual resort to personal and professional values and relationships required for true professional behavior on the other. As we explain in greater detail below, we believe that the defenses students are driven to in response to our standard methods of instruction and evaluation can be highly counterproductive in the context of professional behavior. Because issues of professional responsibility, properly taught, necessarily go beyond strictly legal concerns and professional values to touch on interpersonal matters and issues of individual personality and conscience, students are forced to confront the fact that many aspects of their legal education have systematically disabled them from rising to those challenges. If a course in professional responsibility or the law of lawyering is taught without reference to those broader concerns, students recognize it for what it is: a shallow, Holmesian, rules-oriented, minimalist, "bad man" approach to the one course that, above all others, should attempt to raise their sights and strengthen their resolve to be the best lawyers they can be.

What is wrong with the traditional professional responsibility or law of lawyering courses, then, is not something unique to them. Rather, it is a shortcoming of the law school curriculum in general: its failure to recognize the need for all courses, but particularly those concerned with the professional responsibilities of lawyers, to concern themselves with the temperamental as

12. Undoubtedly there are some such courses that are well thought of by their students. 
well as the cognitive development of their students and to recognize and address barriers to that broader undertaking created by traditional methods of instruction and evaluation.

\section{B. What Would Be Different About a "Good" Professional Responsibility Course?}

How would a professional responsibility course look that made a conscious effort to address the concerns we have raised? There undoubtedly are as many answers to that question as there are interested instructors, but we believe that all would have to share four broad characteristics.

First, the classroom environment would have to be far, far safer than is typical in law school. A setting would have to be devised in which students felt free to discuss issues having strong emotional content without fear that their views would be attacked, ${ }^{13}$ that they would be disrespected, or that their statements would be disclosed or used against them elsewhere. Put positively, the learning environment has to be one in which persons show consideration and respect for one another at all times and view the confidentiality of matters revealed or positions taken in class as sacrosanct.

Second, the learning environment would have to be cooperative rather than competitive to the fullest extent possible. One change entailed by this requirement is the abolition of the forced curve as a way of evaluating student performance. Students in the good class should never be faced with the concern that by helping a fellow student they could be hurting their own chances for a good grade. The overriding goal should be mastery of the material not mastery of other persons. This is particularly so when, as explained immediately below, a principal goal of the course is increased self-awareness gained through shared experiences. Of course, even in such an environment, competition will exist. People will want to get a high grade, and that is just fine. What we want to eliminate is the sort of unhealthy competition in which persons share their knowledge (and themselves) with other students only at their peril. To do that, the forced curve must go. ${ }^{14}$

Third, the good professional responsibility course would devise and adopt a strategy for reaching students at the level of feelings and values, not just at the level of cognition. This is not to say that the law of lawyering is not as complex or as worthy of study as any other body of law. Indeed Professor Schuwerk has devoted his professional life to that subject and sees no higher calling. Nor are

13. We used "attacked" in a technical sense. We do not seek to prevent controversy or expressions of disagreement. We do, however, seek to ban ad hominem criticisms and arguments that invalidate a speaker's feelings or sense of worth. If A disagreed with B, for example, A could say "I disagree with you, B, because in my experience [or as I read the XYZ case] . . ." A should not, however, express his disagreement by saying such things as, "What an idiotic thing to say," or "Everyone I know thinks that's a lot of bull," or "You must be nuts to feel that way."

14. That is not to say that a grading system anything like the one we employed must be utilized. A simple pass/fail system, or an uncurved letter-grade system would do as well. 
we saying that students can substitute "sensitivity" or "caring" for hard knowledge of their professional obligations. Clearly they can not. What we are saying is that viewing the law of lawyering as nothing more than another important body of law to be mastered is a grave mistake. The issues addressed in professional responsibility and law of lawyering courses are not mere intellectual constructs. Rather, they lie at the heart of students' personal relationships, personal values, and personal morality. Lapses in professional behavior are, in our judgment, at least as likely and probably far more likely to stem from those personal attributes than from ignorance of applicable professional norms. ${ }^{15}$ Consequently, a course in professional responsibility or the law of lawyering is falling short of the mark if it does not seek to acquaint students with those aspects of their personalities and sensitize them to the importance of such considerations in their professional lives.

The final feature of the good professional responsibility or law of lawyering course is that it would empower and respect the views of students to a substantially greater extent than occurs in a traditional offering. The good course would recognize that it deals with the most central and critical aspects of students' professional lives: how they will function as attorneys on a daily basis. Its content is ubiquitous and inescapable. As a consequence, the good course would honor students' increased maturity, improved sense of judgment, nascent professional status, and unmatched knowledge of self by providing them, under the broad guidance of the professor, with an important role in deciding the general subject matter areas to be dealt with in the course as well as the particular issues to be surfaced within those areas.

The good course would invest students with this power on pragmatic, pedagogical, and moral grounds. Pragmatism would support that approach, because by treating students as emerging professionals, the course would both model appropriate conduct and maximize the likelihood that students would respond in kind. Pedagogy would support it as well, because students would be much more likely to deeply invest themselves emotionally as well as cognitively in the course if its content and direction were heavily influenced by their own needs and desires for personal and professional growth. Such an investment on the students' part leads to a more soul-stirring and thorough mastery of the course material. Finally, there are moral implications in how we approach the issue of student empowerment in this setting. For us, the key issue is the unique importance of a professional responsibility course to students. Its substance is nothing less than how they will lead their professional lives, an issue

15. We realize this view is controversial, but providing an extensive defense is beyond the scope of this article. For now, we content ourselves with saying that the ABA has concluded that well over one-half of grievances result from lawyers' problems with substance abuse and mental illness. If one were to add to that the number of mistakes committed by lawyers trapped in the delusional folds of rationalization and denial-that is, by lawyers who are aware of applicable disciplinary standards but have convinced themselves that their conduct does not violate them-we believe that we would be including most grievable acts. 
of unsurpassed significance to them not only as lawyers but also as human beings. ${ }^{16}$ To deny students a significant voice in the design and implementation of such a course denigrates their worth as persons.

\section{III}

\section{THE LAW CENTER's EXPERIMENTAL COURSE}

The course was called "Personal and Professional Responsibility" to emphasize that we would go beyond conceptual learning. Consultants helped produce a tentative course outline that dedicated the first month to examining personal behavior patterns, and the second two months to conversing with practicing lawyers, judges, and other professionals about ethical and lifestyle issues.

The three-credit course, which met in one-and-one-half-hour sessions twice a week, was open to second- or third-year students, regardless of prior credit in the required course. The Law Center certified the course as satisfying the school's graduation requirements for professional responsibility. As discussed in greater detail below, the first month was devoted to organized community building to build classroom trust and produce ten high-trust core groups of six students each. We also conducted Myers-Briggs personality typing, introduced Family of Origin theory and exercises, and tied discussion to Stephen Covey's The 7 Habits of Highly Effective People and M. Scott Peck's The Different Drum. For the rest of the semester, we switched to story-telling. Invited guests, mostly lawyers and judges, visited the class singly and in groups of up to three. They told stories and shared their feelings about law practice, professionalism, and ethical problems they had encountered. Students read portions of Deborah L. Rhode's 1994 text, entitled Professional Responsibility: Ethics by the Pervasive Method, in conjunction with those conversations, but we did not ensure compliance or discuss those readings in class. Near the end of the semester, other guests dealt with lawyers' lifestyles, including money management, addiction, and stress.

Grades were assigned strictly on attendance and participation. Students who attended all classes received .5 added to their GPAs; students who attended 90 percent of classes received no adjustment to their GPAs; and students who attended 80 percent of classes were docked .5 . The overwhelming majority of the students attended all classes and were awarded the extra half point, producing a B+ class average instead of the customary B-.

As a class project, each core group produced an essay on improving some aspect of the law profession, and every student wrote an anonymous personal essay describing a positive aspect of the class experience. ${ }^{17}$

16. We reach this conclusion because how students/lawyers choose to lead their professional lives will have profound, if not determinative, effects on how they lead their personal lives.

17. The essays were printed, bound, and mailed as a book to every student. There was one exception to the group-individual essay format. One group combined all its personal essays into a single 


\section{A. What Inspired Us to Design the Experimental Course}

Each of us was attracted to the experimental course format for quite different reasons. For Professor Schuwerk, the course was the outgrowth of his reading and research on the destructive effects of traditional legal education on the personalities and values of many law students. For Professor Mixon, the inspiration for a new approach to teaching professional responsibility was rooted in his earlier article applying quality management principles to law and legal education.

\section{A Course Informed by the Destructive Effects of Traditional Legal Educa-} tion Professor Andrew S. Watson, trained as a psychiatrist, is most noted for his work as both a professor of psychiatry and a professor of law at the University of Michigan. Professor Watson's extensive exploration of the psychological dynamics of the typical law school classroom taught by the Socratic method led him to two profound insights. First, such a legal educational experience is, for many students, an extraordinarily stressful and damaging one. Second, the damage it causes manifests itself most strongly in a student's ability to develop and then actually implement an appropriate ethical understanding of the professional responsibility of lawyers.

Over the course of many years, Professor Watson elaborated upon and explained the reasons for these conclusions. ${ }^{18}$ By and large, his arguments have been met with indifference, skepticism, and, on occasion, outright hostility

\section{group narrative.}

18. Perhaps his most detailed presentation is contained in his 1968 article. See Watson, supra note 5. He notes that almost all law professors are former members of law reviews, a specialized law school subculture based almost exclusively on academic performance. Id. at 107. These professors have little if any practical experience and tend to "see the law in much the same frame of reference in which they studied it-the abstractions of appellate briefs and trial transcripts." Id. While they may have participated in litigation or other activities designed to influence the actions of legislatures and courts, they usually have done so only in elitist settings far removed from the day-to-day activities of most practitioners. Id. at 107-08. Because of their impressive intellectual capacities, many law professors, make excessive use of the defense of intellectualization, whereby people "relate to each other and themselves primarily through ideas, even when emotional matters may be more pertinent." Id. at 113 . They may well be uncomfortable with such emotional considerations, he posits, having never been able to resolve such matters themselves without considerable discomfort and difficulty.

As a consequence, many law professors seem to be completely unaware of the dramatic emotional effects that their (to them) benign teaching techniques have on their students. Id. This blindness leads them to reenact this scene:

I have often been dismayed, especially in the Fall of the year during the first weeks of the term, to hear teachers of freshman classes speak with great glee about how they are busy "destroying the preconceptions" of freshman students. . . . [T] he light in their eye as they describe it suggests that they get too much pleasure from this process. I will not go so far as to use the word sadistic to describe their feeling, but there can be no doubt that they are enjoying their work.

Id. at 109 . The Socratic method as currently practiced is the ideal teaching tool from the perspective of such a personality because it deals largely in abstractions, ignores the emotional needs of those subject to it, "exaggerates and, in a sense, distorts the importance of intellect," and takes as its conscious goal eliminating any role for students' emotions in legal decisionmaking in order to turn them into competent practitioners. Id. at 124. This, Watson concludes, is nothing short of "folly." Id. 
from the academic legal community. In our view, however, his insights have been validated repeatedly by our personal classroom experiences, our conversations with students, our limited acquaintance with both modern quality management and basic psychological principles, and common sense. Only recently, those conclusions also have been confirmed by empirical research on the levels of depression, alcohol abuse, and other substance abuse among law students ${ }^{19}$ and lawyers, ${ }^{20}$ as well as by research on the decline in law students' idealism and reliance on personal, altruistic values as they pass through law school. ${ }^{21}$ Perhaps not surprisingly, those results too have passed largely unnoticed in the legal academic community.

This body of work was available to us as we went about shaping our experimental professional responsibility course. It had a profound influence on many of the decisions we made concerning the course's structure, grading policies, methods of instruction, and content. Because Professor Watson's work has not received the attention it deserves, we address it in some detail.

a. The traumatic effects of a traditional legal education. Professor Watson found that law school teaching by the Socratic method creates intense student anxiety, "as marked as any ... ever seen, including those of troops preparing to embark upon the invasion of Normandy during World War II.",2

Why does the Socratic method create such extraordinary levels of anxiety? "Most members of a freshman class are brought nearly to panic by their awareness that they do not understand what is being demanded of them, nor can they figure out how to meet the pressure."23 Students try to deaden the psychic pain caused by this level of anxiety by using "anxiety-muting defenses" in ever broadening areas of their lives to "block emotional awareness." "Many

19. See G. Andrew H. Benjamin et al., The Role of Legal Education in Producing Psychological Distress Among Law Students and Lawyers, 1986 AM. B. FOUND. RES. J. 225 (1986).

20. See G. Andrew H. Benjamin et al., The Prevalence of Depression, Alcohol Abuse and Cocaine Abuse Among United States Lawyers, 13 INT'L J. L. \& PSYCHIATRY 233 (1990). For an important article outlining an approach to alleviating the conditions of distressed lawyers, see Amiram Elwork \& G. Andrew H. Benjamin, Lawyers in Distress, 23 J. PsYCHIATRY \& L. 205 (1995).

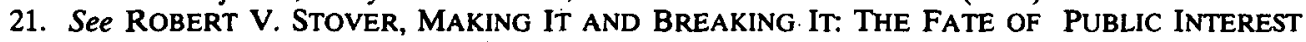
COMMITMENT DURING LAW SCHOOL (1989); see also David Raack, Essay Review: Law School and the Erosion of Student Idealism, 41 J. LEGAL EDUC. 121 (1991) (reviewing Professor Stover's book).

22. Andrew S. Watson, A Psychiatrist on the Law School Faculty: Influences on Professional Careers, 16 LAW MED. \& HEALTH CARE 240, 242 (1988) (emphasis added). We realize that this claim may seem to be utterly astounding to many law professors, whose experiences in law school may have been among the happiest of their lives. All of us must remember, however, that law professors may be uniquely blinded to the perceptions of law school described by Professor Watson. We are the annointed of the system of legal education as it is. We thrived under that system and succeeded on its terms, so it is understandable that we find it difficult to comprehend the reactions Professor Watson documents.

Nonetheless, the overpowering nature of this effect should not be underestimated. Professor Watson commented that "sitting in the rear of the class as a visiting professor, not being subject to being called upon nor having to pass examinations, [I] found myself to be reacting in exactly the same way my "classmates' were." Id. at 241-42.

23. Andrew S. Watson, Some Psychological Aspects of Teaching Professional Responsibility, $16 \mathrm{~J}$. LEGAL EDUC. 1, 13 (1963). 
law students will progressively surround themselves with a suit of psychological armor that makes them more and more impervious [not only to the immediate stresses of the classroom setting but also] to the emotional aspects of most, if not all, situations."24

Perhaps the most profound and far-reaching consequence of this adaptation is its significant impairment of character formation, with a resultant crippling of a student's ability to behave in a professionally appropriate manner once in practice. $^{25}$ This problem stems from the extreme emphasis law schools place on being "intellectual" and "unemotional" in examining and resolving legal issues. $^{26}$ While this adaptation may be useful in a classroom setting, it is deadly in real life where "the core of professional activity involves dealing with emotions and emotional conflicts." 27 No person can deal with such reactions effectively without knowing his or her own blind spots and vulnerabilities. ${ }^{28}$ A traditional legal education, however, builds up barriers to such understanding, ones that can last a lifetime.

b. Evidence supporting Watson's views. If we were to ask any law teacher whether he or she thinks legal education is "stressful," we venture to predict that 99 out of 100 would say "yes." However, most would not be thinking that the stress they had in mind was a bad thing. In fact, if our experience in that regard is typical, most would view it as anywhere from necessary to benign-as an ordeal by fire that leaves students with personalities better suited to the practice of law than those they came with to law school. In a similar vein, we also believe that most legal educators would not be thinking of the stress levels generated by a legal education as anything likely to be particularly harmful. Few if any would deem it even plausible that the stresses involved would produce severe illnesses in any but a few especially susceptible individuals with pre-existing pathologies.

A recent study conducted by the American Bar Foundation ("ABF") says that rosy view is mistaken. ${ }^{29}$ Its basic conclusion is that a typical legal education takes a group of highly intelligent, intellectually curious, and eager students with only average numbers suffering from serious mental health or substance abuse problems and roughly quadruples the number having such infirmities by the time they graduate three years later. ${ }^{30}$ In 1990 , a similar

24. Id.

25. Watson, supra note 5 , at $130-32$.

26. Id. at 131.

27. See Watson, supra note 23 , at 14 .

28. Id.

29. See Benjamin et al., supra note 19.

30. The study found that while prelaw students had roughly the same frequency of "high stress level" members as the general population (approximately $10 \%$ as opposed to $8-9 \%$ for the country as a whole), by the end of the first semester of law school, that figure had risen to $27 \%$, by the end of the first year to $34 \%$, and by the end of the first semester of the third year to $40 \%$. Id. at $236,246-47$. It is important to bear in mind that these studies were not looking just for some level of depression among their student subjects. What they were noting were clinical levels of depression-that is, levels of 
study was made of a population of lawyers in the state of Washington. ${ }^{31}$ Not surprisingly, the results were very similar to those noted for law students. ${ }^{32}$ After eliminating double-counting of lawyers with multiple impairments, the study concluded that one in three lawyers was clinically impaired by depression, alcohol abuse, or cocaine abuse. ${ }^{33}$ These profoundly disturbing studies should have started a legal educational revolution. So far, however, they seem to have been largely consigned to oblivion.

In attempting to explain their findings, the authors of the ABF study came to the same conclusion Professor Watson had reached years before: "[c]onventional legal education that concentrates on the development of analytic skills while ignoring interpersonal development may increase distress levels and prevent the alleviation of symptoms." 34 Such an approach, they surmised, has the "unintended consequences" of conditioning students to take an impersonal or intellectual approach to their own and others' primarily emotional experiences. The authors concluded that an overly detached approach is flawed because it does not "touch upon the psychological sore points that create anxiety for the individual student lawyer" 35 and actually makes attorneys "less skillful in dealing with the emotional tensions which are so much a part of the lawyerclient relationship."36

Those conjectures find considerable support in the studies suggesting that as many as 60-80 percent of all grievances and malpractice actions brought against lawyers are associated with problems of mental illness and substance abuse. ${ }^{37}$ Many of our profession's most serious shortcomings therefore appear rooted at least in substantial part in the damage caused by our current educational efforts and compounded by the stresses encountered in the practice of law.

depression two or more standard deviations from the norm of a normal population. Only $1.2 \%$ of such a population (consisting of persons not in active treatment for depression) would exhibit the levels of depression noted above. Id. at 227-28. These results, the authors concluded, were consistent with an earlier study that had found that as students progressed through law school, from $17-40 \%$ suffered clinical levels of depression and from $20-40 \%$ reported significantly elevated levels of many other psychological disorders, "including obsessive-compulsive, interpersonal sensitivity, anxiety, hostility, paranoid ideation and psychoticism (social alienation and isolation)." Id. at 236.

31. See Benjamin et al., supra note 20.

32. The Washington study found that (1) $19 \%$ of all lawyers suffered from clinical levels of depression, accompanied by frequent thoughts of suicide, (2) $18 \%$ of all lawyers with $2-20$ years of practice, rising to $25 \%$ for those with more than 20 years of practice, suffered from clinical levels of alcohol abuse, and (3) at least $1 \%$, and probably many more, of all lawyers suffered from clinical levels of cocaine abuse. Id. at $240-41$.

33. Id.

34. See Benjamin et al., supra note 19 , at 250.

35. Id at 251 (quoting Leonard D. Eron \& Robert S. Redmount, The Effect of Legal Education on Attitudes, 9 J. LEGAL EDUC. 431, 441 (1957)).

36. Id. at 251 (quoting Andrew S. Watson, Some Factors in the Contemporary Regulation of the American Legal and Medical Professions 9 (Issaac Ray Lecture, University of California at Berkeley Law School, 1979)).

37. Id. at 243-44 and authorities cited therein. 
c. The impact of a traditional legal education on the development of a student's sense of professionalism. A major theme of Professor Watson's work has been the particularly devastating effects that the defenses students erect in order to cope with the stresses of the traditional law school curriculum have on their nascent sense of professionalism. At bottom, all significant professionalism issues beyond basic intellectual competence are based on personal and professional values, emotion-laden subjects for us all. Students taught to deny, denigrate, or conceal from themselves the importance of such basic human wellsprings of character and virtue will be rendered virtual professional cripples.

How should we teachers of professional responsibility go about restoring to students the innate ability to grapple openly and successfully with the issues of professional responsibility that will permeate their practices? The first thing, according to Professor Watson, is to put students back in touch with their emotional selves and give them the tools, resources, and courage necessary to face and resolve emotion-laden issues. ${ }^{38}$ Teaching students the substance of applicable ethical codes will remain largely ineffectual and "very possibly negative" unless used "primarily as launching points for further discussion . . . of emotional conflicts which students (and teachers) generally seek to avoid."39 In most instances where ethical dilemmas arise, unprofessional behavior does not occur because the lawyer did not know what the applicable ethical rules were. Instead it occurs either because the lawyer has obscured or distorted the applicability of those rules with the defenses of denial and rationalization or because the lawyer has chosen not to conform to those rules. ${ }^{40}$

The second thing that we must do is to avoid belittling the legal profession or the actual practice of law. Perhaps so many of us do this so freely because we feel that we have little influence over our students. Quite the opposite is

38. Elsewhere, Professor Watson addresses a concern that we find prevalent among teachers with whom we have discussed our course: that it runs the risk of "invading the privacy" of participating students by surfacing emotional concerns. See Watson, supra note 22, at 245-46. Professor Watson acknowledges that while many personal experiences from a person's remote or recent past are private and should be protected, the notion that emotions themselves are private, purely internal matters is indefensible. "The fact is that in all human interpersonal relationships emotions are churning about and spewing forth all over the place. They are very public." Id. at 245.

In all classrooms, and especially in a Socratic classroom, the teacher stimulates, and with cold malice aforethought, a whole multitude of emotional reactions. He does not have "an informed consent" to do this, but that does not forestall him from carrying out intellectual explorations in a way that insures the free flow of all of these powerful emotions.

Id. Perhaps it is those enamored of the so-called Socratic method who should take stock of their teaching techniques if the emotional welfare of students is of such concern to them.

39. Andrew S. Watson, Lawyers and Professionalism: A Further Psychiatric Perspective on Legal Education, 8 U. MiCH. J. L. REF. 248, 251 (1975).

40. A recent article has observed that "lawyers are experts at defending themselves through the use of denial and rationalization." Amiram Elwork \& G. Andrew, H. Benjamin, Lawyers in Distress, 23 J. PSYCHIATRY \& L. 205, 218 (1995). 
true, however, at least initially. ${ }^{41}$ While we see our charges as exceptionally mature and able graduate students, Professor Watson cautions us that is not the case. In large part because of the traumatic effects of much current legal education pedagogy, "[t]he psychological position of law students [is comparable to that of] relatively helpless children who must place their whole dependence upon parents for supplying crucial needs and protecting vital interests," and who have "no capacity to judge the useful from the inappropriate in the beginning." ${ }^{42}$ If Professor Watson is correct, then especially during the first year of law school, we wield vast power over our adult charges.

This enormous influence can be used for good or ill. If we want to maximize the likelihood that our students will view the thoughtful and humane resolution of ethical practice issues as both important and attainable, they must see that we value that behavior ourselves. They will judge our sincerity first and foremost by how we treat them and by how we view the practice of law. If we want to minimize the likelihood that they will pay any attention to what we say, few steps are apt to be more effective than a callous disregard for their professional development coupled with a drumfire of disparagements of the bar as irredeemably greedy, self-centered, and corrupt.

The third thing that we must do is to provide students with worthwhile examples of the kinds of professional behavior that we expect them to emulate. As Professor Watson put the matter elsewhere, "[t]here will never be too many opportunities to raise and explore solutions to the myriad themes and variations on professional difficulties that arise in the practice of law." ${ }^{43}$ However, this idea has its critics. All of us have heard our colleagues bemoan the idea of teaching or even trying to teach professional values to our students. The task is useless, we have all been told, and none of our business anyhow.

Professor Watson disagrees. He counsels us that while law students have well-formed personal values stemming from family, church, and society, they nonetheless have relatively unsophisticated and unformed ideas of what it means to be a "good lawyer." 44 Moreover, students realize that and look to their legal education to provide them with the necessary skills and values to become "good lawyers" in both a technical and a moral sense. ${ }^{45}$ "The universal human need to have objects for modeling and identity formation may be the single most important psychological factor in the educational process," and one that makes "the form and process of legal education so crucial as they relate to the shaping of professional behavior." ${ }^{46}$ Consequently, it "borders on irresponsibil-

41. This influence would be longer lasting and more profound if exercised in a more beneficent manner.

42. Watson, supra note 23 , at 10.

43. Id. at 20.

44. See Watson, supra note 22 , at 249-50.

45. See Watson, supra note 5, at 105-06.

46. Watson, supra note 22 , at 250. 
ity to leave the professionalizing process to the random adventitious experiences of post-law school encounters." 47

What models of professional behavior will our students adopt? Either those we put forward (which, if we so desired, could include living, breathing practitioners as well as legal legends) or those they find on a hit-or-miss basis in their own encounters with the profession. If we believe that the exemplars we could advance would be better than those served up by chance, then we must undertake that task. ${ }^{48}$

d. Other evidence supporting Watson's observations. If Professor Watson's views on the effects of a traditional legal education on students' sense of professionalism are well founded, we might expect to find evidence of the effects in at least two areas. The first would be in the students' reaction to a traditional, rule-oriented professional responsibility course. Students should find such a course very unrealistic, unsatisfying, and frustrating. It would strike them as unrealistic because they would have no reason to believe that lawyers actually worry about the rules, except in extreme cases. It would be unsatisfying because it would not appear to grapple with what students consider the viscerally, as opposed to the intellectually, "hard" issues. It would consist mostly of cases drawing what students would consider to be esoteric disciplinary lines in the dust and then seeing how close one could get without crossing over-hardly a satisfactory approach to ethical issues, however appropriate it might be for other areas of the law-while the affective dimensions of the cases at issue would be largely ignored. Finally, it would be frustrating because it would not give students the wherewithal to deal with ethical issues from a position of moral strength. Students might learn what they should do, but feel no confidence that is what they would do. ${ }^{49}$

If indeed students did experience these emotions, one would expect them to evaluate the course and instructor quite harshly. While we have only anecdotal

47. Id.

48. Lest we decide that we have better things to do, we should consider this final admonition from Professor Watson:

Professionalism in the last analysis is related to idealistic behavior, and a failure to make this kind of identification must categorically be viewed as a serious academic omission. I believe that successful legal education must pay conscious and continuous attention to such problems of idealism, and the psychological dynamics of developing a professional attitude must be comprehended [by us] and fully utilized. I realize that idealism is not a goal which law teachers deliberately seek to implant in their students; indeed, it is suspect. However, it is a psychological necessity for a person to make such an identification if he is to function as a professional. ... Of course, I do not believe that mere exhortations will alter behavior. However, disciplined and tutored exposure to the stresses of professional life with opportunities for exploring the meanings of such encounters can do much to alter human behavior.

Watson, supra note 5, at 127.

49. This may strike many of you as an unduly harsh criticism of a traditional treatment of a field that is genuinely intellectually complex. Nonetheless, the one of us who has taught such a traditional course for many years believes that it is a realistic rendition of many, if not most students' assessments of that offering-as taught both by him and by others. 
evidence supporting this premise from anywhere except our school, it is borne out here. Year in and year out, Professional Responsibility consistently ranks in the bottom 5 to 10 percent of all courses taught, no matter who teaches it and no matter how well those teachers are thought of in their other courses.

A second source of support for Professor Watson's views would be a sharp decline in the favorable attitudes of law students toward areas of the law that are overtly idealistic in character: public service (pro bono) or public interest law. In fact such a decline has been widely documented. ${ }^{50}$ According to survey data, that work "exhibited the greatest decline in any category over the course of law students' careers." ${ }^{51}$ Students' expectations that those jobs would allow them opportunities to do "altruistic" work, to advance their own social or political goals, to help people or causes with which they sympathized, or to engage in innovative or challenging legal tasks, all declined during that time period. ${ }^{52}$ These results were all readily predictable based on Professor Watson's work. The cogency of his arguments and the empirical support for his positions convinced us that the destructive factors of a traditional classroom approach had to be neutralized if our course were to succeed. The question was just how should that be done.

\section{B. A Course Design Based On Systems Theory And Quality Management Principles}

In an earlier article, Professor Mixon applied quality management principles to law and legal education. ${ }^{53}$ That article proposed that the professional responsibility course deal directly with students' commitment to professional values and teach about a lawyer's life by exposing students to practicing attorneys. ${ }^{54}$

Professor Mixon readily accepted Professor Schuwerk's invitation to develop a course implementing those proposals. Building on that earlier work, he designed a course incorporating his lay understanding of recent best-sellers on

50. The most complete recent treatment of that trend is Professor Robert V. Stover's book, supra note 21. See also Raack, supra note 21 (summarizing Stover's principal findings and those of his predecessors). Professor Raack determined that those studies showed that an emphasis on bar and business oriented courses, as well as the most commonly employed pedagogical approaches and methods-such as a single-minded devotion to "hard" supposedly value-free legal analysis, overemphasis on "borderline" cases, and overuse of the Socratic method-leave students with the impression that public interest activities are unimportant and uninteresting. Raack also noted a marked tendency for students to decide that the moral values they brought with them to law school inclining them towards such work are irrelevant to the practice of law. Id. at 124-33. These factors, as well as others, led to a marked decline in student interest in law reform or other public interest careers. Id. at 123-24.

51. Id. at 123 .

52. Id. at 123-24.

53. John Mixon \& Gordon Otto, Continuous Quality Improvement, Law, and Legal Education, 43 EMORY L.J. 393, 463 (1994).

54. Id. at 462 . To prepare students to serve the public better, law schools might help students look deeply into their own psyches to see whether they are emotionally equipped to participate in the law service system as professionals and to determine which aspect of practice is best suited to their individual personalities. Id. 
business management, ${ }^{55}$ brain theory, ${ }^{56}$ and a variety of self-improvement books. $^{57}$ Several consultants ${ }^{58}$ provided recommendations and insights, and others served as teachers. ${ }^{59}$

The design of the course was heavily influenced by W. Edward Deming's "Continuous Quality Improvement" theories, but the most pervasive aspect was systems theory, including family system theory. As set out in greater detail below, the course implemented systems theory, as we understand it, by incorporating community building, family systems epistemology, family of origin inquiry, personality-typing, personal involvement and interaction with lawyers and clients, and commitment to a shared vision of maximum personal satisfaction for our graduates in well-led professional lives.

Systems theory was particularly helpful because it reminded us that we would be dealing with the different perspectives of sixty students individually working out how they would function in a dynamic professional world. Solutions to the ethical dilemmas they would face would not be simple, and could not be provided solely by rules that students could memorize and apply mechanically. Moreover, as they grappled with those issues in class, each student would be coming to us with a different personality, learning style, and value system, which have been forged over decades by forces that were far more powerful in the student's life than we could ever hope (or desire) to be. It would be necessary to develop a model of learning that could incorporate that enormous diversity of outlook and experience and use it to foster personal insight and growth rather than fractiousness and withdrawal.

We realized we could not reach students' spirits and souls by preaching, assessing blame, or advocating some ideal ethical world. Instead, we had to look for leverage points and provide students personal space and inspiration for individual development. We had to become part of the students' learning system, working as facilitators and team members to create opportunities for learning. We settled on two primary approaches. The first was to employ

55. Stephen R. Covey, The 7 Habits of Highly EfFective PeOPle (1989); Philip B. CROSBY, Quality Without Tears (1984); PHILIP B. CROSBY, Quality IS FreE (1979); DeMING, supra note 2; ANDREa Gabor, THE MAN Who Discovered Quality (1990); JoHN W. HARRIS \& J. MARK BaggetT, QuAlity QUEST IN THE ACADEMIC ProCess (1992); Alfie KoHN, No ConTEST: THE Case Against CoMpetition (1992); The New PARAdigm In Business (Alan Ray and Michael Rinzler eds., 1993); Peters, supra note 10; ThOMAS J. PETERS \& ROBERT H. WATERMAN, JR., IN SEARCH OF EXCELLENCE: LESSONS FROM AMERICA'S BEST-RUN COMPANIES (1982); SENGE, supra note 3; MARY WALTON, DEMing MANAGEMENT AT WORK (1990).

56. Leslie A. HaRT, Human BRAin AND Human LeARning (1983); JUdith HoOper \& DiCK TERESI, THE 3-POUND UNIVERSE (1986); RICHARD RESTAK, THE BRAIN HAS A MIND OF ITS OWN: INSIGHTS FROM A PRACTICING NEUROLOGIST (1991); STEVEN ROSE, THE MAKING OF MEMORY: FROM MOLECULES TO MIND (1992).

57. See, e.g., DEEPAK ChOPRA, UnCONDITIONAL LifE (1991).

58. These include Donald Williamson, Ph.D., Stella Rabaut, Linda Webb, and dozens of lawyers and judges who responded to the proposed course design.

59. At the continuing service level, Tom Peery was community builder, Newton Hightower, Ph.D., was Family of Origin lecturer, and Shirley Steer administered and explained the Myers-Briggs type indicator. 
experts to apply family systems theory to encourage students to find the source and content of their individual behavior patterns so they could acknowledge and reflect on anything they found troubling. The second was to expose students to practitioners in face-to-face conversations where the students could be touched by the professional's emotion.

We intended our approach to be the very antithesis of the traditional law school pseudo-Socratic ${ }^{60}$ method of instruction, with its emphasis on "hard" cases and supposedly rigorous and rational cognitive processes at the expense of students' emotions, feelings, and values. These traditional techniques desensitize students to the critical role of interpersonal skills in all aspects of a professionally proper attorney-client relationship and, for that matter, in all aspects of an ethical law practice. They also set students' moral compasses adrift on a sea of relativism, in which all positions are viewed as "defensible" or "arguable" and none as "right" or "just," and they train students who recognize and regret these developments in themselves to put those feelings aside as nothing more than counter-productive relics from their pre-law lives.

In designing the new course, we sought to reawaken and re-energize our students' capacities to make reasoned moral judgments. We hoped exposure to persons for whom ethical issues loomed large in their professional lives would grab students' attention, give them a feeling of community with ethical lawyers, and encourage them to model their own conduct after good behavior. We disciplined ourselves to stay out of the way as students drew their own conclusions from raw data, a learning process judged more effective than a lecture on or discussion of pre-digested conclusions. ${ }^{61}$

60. We refer to the technique as "pseudo-Socratic" because, in one of the great ironies of history, it embodies not the methodology of Socrates, but rather that of his great rival, the Sophist Protagoras. See W. C. Heffernan, Not Socrates, But Protagoras: The Sophistic Basis of Legal Education, 29 BUFF. L. REV. 399, 400 (1980). It was Dean Langdell who first referred to the method as "Socratic," id. at 402 , and so it remains to this day. Although widely used, this technique has been criticized as being disempowering, anxiety producing, and confusing for students, while overemphasizing the combative nature of law. See J.T. Dillon, Paper Chase and the Socratic Method of Teaching Law, 30 J. LEGAL EDUC. 529 (1980); Paul T. Hayden, On "Wrong" Answers in the Law School Classroom, 40 J. LEGAL EDUC. 251 (1990); James B. Taylor, Law School Stress and the "Deformation Professionelle", 27 J. LEGAL EDUC. 251, 254 (1975). For efforts to salvage the technique, see Steven A. Childress, The Baby and the Bathwater: Salvaging a Positive Socratic Method, 7 OKLA. CITY U. L. REv. 333 (1982); June Cicero, Piercing the Socratic Veil: Adding an Active Learning Alternative in Legal Education, 15 WM. MITCHELL L. REV. 1011 (1989).

61. For an argument that students learn best from unorganized data to which they can apply and develop personal patterns of understanding, see LESLIE A. HART, HUMAN BRAIN AND HUMAN LEARNING 60-68 (1983).

[T]he worst aspect of classroom input is oversimplification. By tradition and logic, teachers try hard to organize their presentation and reduce its apparent difficulty, in the firm belief that the simpler, more restricted, and clearer input, the more easily and certainly it will be grasped. Such is the power of logic and common sense that the constant failure of this belief to produce the hoped-for results may be given little heed; and when I show educators, from their own familiar experience, that the process of learning is the extraction of patterns from confusion-not from clarity and simplicity - they usually find that view at first hard to credit, and a distressing turning upside-down of previous assumptions.

Id. at 74-75. 
1. Family Systems Theory. The biggest challenge we faced was getting students to look at their individual value structures. Our consulting family systems theorist recommended that we start the course with family of origin inquiry, which holds that fundamental patterns of behavior are transmitted from generation to generation by subtle messages that are picked up, recorded in the emotionality of the family member, and acted on throughout life. The intense family experiences of early childhood are the single most influential factor in determining how one responds to intimacy, acquires motivation, makes moral choices, handles loss, manages stress, and even creates health and sickness. ${ }^{62}$ In other words, "the individual creates all of his or her own reality in life. There is no 'out there,' immutable, objective psychosocial truth about anything. There are only the inside personal meanings which we create for ourselves."63 The clear message of this theory is that every observer deals with the world through sense perceptions that are processed according to the observer's unique genetically and environmentally determined brain patterns.

To the extent that autonomy and personal improvement are possible, the process must begin with self-awareness and understanding. Otherwise the unexamined patterns developed in early childhood can disable a grown-up professional from performing effectively as an attorney. For example, an otherwise mature lawyer who responds to authority figures with the patterns of response used in relating to a father, mother, or sibling ( with, for example, belligerence, anger, excessive submissiveness, or passive-aggressiveness) cannot deal effectively with judges, police, senior partners, or opposing lawyers. A lawyer whose family of origin transmitted unresolved grief from generation to generation may turn to alcohol or drugs to mitigate the pain. ${ }^{64}$ If guilt was the preferred family control mechanism, the grown lawyer will employ the same strategies in dealing with clients, associates, secretaries, and spouse. A lawyer whose family of origin made a game of covert law-breaking is not likely to worry about unethical behavior that can be kept secret. When these patterns

62. Donald S. Williamson, Personal At-Ease, Physical Dis-Ease, and Intergenerational Family Experience, Edition of Topics in Counseling and Family Psychology. Thus explained, family systems theory leaves little hope for self-direction, moral improvement, or any other behavioral change that does not operate by way of conditioning or chance. The Family Systems advocates themselves admit this difficulty. "Like psychoanalysis, transgenerational therapy can inadvertently give the impression that it is a process that never ends. It may be fair to say that this is in part because transgenerational family therapy is somewhat pessimistic about significant change being possible in any circumstances. It certainly is hesitant about lasting change coming in a relatively short time." DONALD S. WILLIAMSON, THE INTIMACY PARADOX: PERSONAL AUTHORITY IN THE FAMILY SYSTEM 15 (1991). But that is not the case. Brain activity is physical, or at least has physical aspects. HOOPER \& TERESI, supra note 56. Every thought that finds its way into memory strengthens or weakens an existing neural pattern, and may become incorporated as a property of "the entire brain, even the entire organism." RosE, supra note 56 , at 271 .

63. Williamson, supra note 7 , at 29.

64. A tendency toward addiction may also, of course, be genetically transmitted. See JON Franklin, Molecules of The Mind: The BRave New SCIENCE Of Molecular PsyChology 5059 (1987). Personal acknowledgment of this family tendency is essential if the student/lawyer wants to avoid dependency. 
of behavior are examined consciously and reflectively, however, the act of acknowledging and evaluating them introduces a new influence on future behavior. ${ }^{65}$

The implications of family systems theory and learning theory for a course in lawyer's ethics are enormous. First, a course that concentrates on rules, principles, or cold reports of other people's behavior is unlikely to have a lasting impact on students because it lies outside their own universe. Second, to create any hope of inner change, a course must open up those unseen, unacknowledged, unquestioned, often unknown patterns that have been determined by, transmitted through, and perpetuated by one's family of origin. ${ }^{66}$

This is scary business, both for students and professors. A law school course that probes family history and proposes to re-wire student brains is open to criticism. Certainly, no one, no matter how well-intentioned, should try amateur or even professional psychotherapy in a law school course. We determined to stop well short of that point, but to risk venturing beyond mere verbal inquiry. Pedagogical ethics aside, before we could attempt any of this, we had to create an hospitable environment for open discussion of personal values.

2. Community Building. Law school is not a safe place for students to reveal much about themselves. For three years, professors and classmates pounce on any vulnerability and engage in ritual combat, supposedly to sharpen skills and prepare for real life. As a result, defensiveness replaces any pre-law vulnerability. Vulnerability is essential for self-examination and growth ${ }^{67}$ but no one is going to become vulnerable unless the environment is safe.

We tried to make the class a safe place where students could reveal personal thoughts without fear of betrayal. We wanted to create a feeling of trust and safety for the entire class of sixty students, and an even higher level of trust in smaller, more intimate groups. This environment could be established only through a structured group process that required individual involvement at a moderately intense level. Again, we looked to business management for help. ${ }^{68}$

65. Williamson, supra note 7, at 72. The reflection principle apparently applies, even for as meaningless a matter as nonsense words. A study indicates people put personal evaluations on virtually all perceptions, including nonsense words, such as "Juvalamu" (which brings more pleasure to English speakers than "Chakaka"), but "[e]ven if we have an automatic like or dislike of someone in the first moment, if you're aware of your bias and mull over what you think, that adds information that overrules the unconscious judgment." Daniel Goleman, Brain May Tag a Value to Every Perception, N.Y. Times, AUG. 8, 1995, at B5.

66. For a description of family systems theory and therapy and its use to produce personal autonomy, see Williamson, supra, note 7.

67. PECK, supra note 4, at 67-70, 226-33.

68. Professor Mixon had tried and discarded instructional use of group process at the Law Center in the 1970s. Based entirely on a National Training Laboratory T-group model, the process proved too intense and too invasive of participants' personal lives. A Systems seminar sponsored by Pegasus Communications, Inc., in fall 1994 advanced a modified group process that proved ideal. 
Although the leader in the development of community building techniques, M. Scott Peck, ${ }^{69}$ was beyond our means, we were fortunate to find a Houston community builder who planned and conducted the first month of classes. ${ }^{70}$ It was not an easy assignment. Our course attracted more students than are normally included in a community-building group, and our classroom setting was not conducive to the activities we needed to conduct and the atmosphere we wished to create. Most importantly, we had far less time (and in far shorter blocks) than is usually employed in community-building activities. Despite those obstacles, however, students felt they had reached a workable level of community in three or four one-and-one-half-hour classes.

3. Modern Quality Management Principles. Quality management differs dramatically from what was taught in business schools and practiced in industry before the 1980s. In its current forms, it is called "Continuous Quality Improvement," "Quality Control," or "Total Quality Management" ("TQM"), depending on which of several gurus is the point of reference.

During the past half-century, quality theories have been refined and promoted in Japan and then in the United States by W. Edwards Deming, ${ }^{71}$ J. M. Juran, ${ }^{72}$ and Phillip Crosby. ${ }^{73}$ Walter Shewhart developed the basic notions at Bell Laboratories during the $1930 \mathrm{~s} ;{ }^{74}$ the Allies applied quality principles with deadly efficiency to win World War $\mathrm{II}^{75}$ and the Japanese embraced them as a post-war tactic that enabled them to dominate the automobile and electronic goods market. ${ }^{76}$

Although originally developed for industries producing tangible goods, quality management can apply to education, law practice, and productive life in general. Paraphrased, its eight major precepts are that (1) every productive activity has customers, ${ }^{77}$ both within and outside the enterprise, (2) the only

69. The psychiatrist M. Scott Peck spent several years developing community-building techniques for religious and business groups. See PECK, supra note 4. By using these techniques, most groups achieved a feeling of closeness and "community" characterized by a high sense of trust, an absence of formal leadership, and acceptance and respect for all members' ideas and points of view. Id. at 59-85, 107-18.

70. Tom Peery, a retired industrial manager, applies the Peck method to community building in Houston for clients who include churches, businesses, and jails.

71. DEMING, supra, note 2; GABOR, supra, note 55; Watson, supra, note 5.

72. JOSEPH M. JURAN, JURAN ON LEADERShIP FOR QUALITY (1989); JOSEPH M. JURAN, MANAGERIAL BREAKTHROUGH (1964). 55.

73. CROSBY, QUALITY IS FREE, supra note 55; CROSBY, QUALITY WITHOUT TEARS, supra note

74. Walter A. Shewhart, Economic Control of Quality of Manufactured Product. (1980); DEMING, supra note 2, at 3.

75. GABOR, supra note 55, at 53-57.

76. DEMING, supra note 2 , at 3-4, 10-11, 18, 64-100.

77. Id. at 5. Customer satisfaction does not have a necessary merchandising connotation. A customer is anyone who receives a good or service from someone else. A customer in a restaurant, for example, is a customer, but so is the cook who wants to get a clear direction from the waiter on what to cook, the set-up person who needs to be satisfied with instructions on where to place knives and forks, the restaurant owner who wants to receive satisfactory fruits and vegetables, etc. In a law office, the secretary is a customer of the lawyer and needs to receive clear and respectful instructions. 
useful measure of quality is whether goods or services satisfy those customers, ${ }^{78}$ (3) to survive and prosper, producers of goods and services must constantly strive to enhance customer satisfaction, ${ }^{79}(4)$ management decisions should be based on fact, not beliefs, with constant feedback to measure success or failure ${ }^{80}(5)$ cooperative efforts, a win-win attitude, and pursuit of a common vision are essential for quality improvement, ${ }^{81}(6)$ people work best and are happiest when the reward is intrinsic, ${ }^{82}(7)$ competition, extrinsic rewards and merit ranking of individuals destroy incentive and breed destructive behavior, ${ }^{83}$ and (8) a "systems" perspective is essential for a manager to understand and manage any process. ${ }^{84}$ These principles justified a significant part of the Keck grant and were employed throughout the design and implementation of the experimental course. In general terms, the principles guided us in assessing our "customer's" attitudes and responding to their concerns in promoting cooperation within the class.

a. Assessing "customer" attitudes. We viewed our students as our most obvious customers. ${ }^{85}$ Their collective opinion, as measured by the students' course evaluations and perceptions of the legal profession, was that our conventional efforts needed improvement. No formal survey was needed to know that students wanted a more interesting, meaningful, and useful course. ${ }^{86}$ To test our proposal's customer appeal, we conducted three student focus groups in the semester just prior to instituting the course and solicited input from several leading lawyers and judges. Most voiced total support, although a few doubted we could maintain personal safety, and others wondered whether our efforts came too late to affect student behavior. ${ }^{87}$

b. Responding to "customer" concerns. As we discuss in greater detail below, we constantly sought student feedback on the experimental course as it

78. Id. at $167-247$.

79. Id. at 49 .

80. Id. at 309-88.

81. William W. SCherkenbach, THE DEMING Route to Quality aND PRoductivitY 57, 128 (1991).

82. W. EDWARDS DEMING, THE NEW ECONOMICS FOR INDUSTRY, EDUCATION, GOVERNMENT 11415 (1992).

83. Id at 22-25, 113-17. Joyce Nilsson Orsini, Bonuses: What Is the Impact?, NAT'L PRODUCTIVITY REV. (Spring 1987), reprinted in DEMING, supra note 82, ch. 16.

84. DEMING, supra note 82 , at $46-81$.

85. The course also served the profession at large, employers, clients, and the general public by producing law graduates committed to ethical conduct.

86. Student evaluations for three years produced, on average, a course rank in the bottom $5 \%$ of courses offered at the Law Center. For a lengthy and thoughtful articulation of problems in the profession, see SOL M. LINOWITZ, THE BETRAYED PROFESSION: LAWYERING AT THE END OF THE TWENTIETH CENTURY (1994).

87. We did not try to sample the public at large, but we strongly believed they thought lawyers' professional behavior needs to be improved. The 1995 Texas Poll asked 1,001 people to rate their level of confidence in various government agencies and other institutions. The legal profession ranked next to the bottom, 21 out of 22 , far below policemen, the Texas Legislature, and television reporters, with only the NRA getting a lower level of trust. HouS. CHRON., Aug. 20, 1995, at 3E. 
progressed. Perhaps more important than seeking such feedback was that we actually paid attention to it. Quality management principles say, in effect, that "fifty million frenchmen can't be wrong." We do not mean to suggest that ethics course instructors should cede control over the content and method of instruction in their courses to their students. However, the students should be listened to with respect when they say that certain pedagogical techniques are counterproductive, superficial, or ineffective, that a professional responsibility or law of lawyering course is shallow, mean-spirited, uninspiring, or meaningless, and that to be of value to them, the course should be modified. After all, it is their professional lives-and, to a substantial extent, their personal lives-that are at stake.

c. Promoting cooperation and win-win. We also took quality management theories into account in designing our course evaluation criteria. All such schools of thought say cooperation and win-win behavior are essential for improving quality, while competition and merit-ranking are detrimental. Direct, zero-sum grade competition among students in the experimental course would have disabled them from openly and honestly discussing personally held values. Accordingly, we had to convert win-lose classroom combat to win-win trust by eliminating the forced curve that locked students in direct grade competition. The grading system we devised, while far from ideal, did accomplish that objective.

d. Intrinsic Rewards. In law school, grades represent the extrinsic reward; enjoyment of learning, a sense of growth, amicable associations with other students, etc., are intrinsic rewards. Course feedback indicates that students saw the predominant rewards of the experimental course as intrinsic. In their anonymous assessments, they repeatedly stressed how excited they were about the learning atmosphere the course achieved and how deeply they appreciated the sense of camaraderie that developed in their core groups.

4. Personality Typing: Carl Jung and Myers-Briggs. As part of our efforts to give our students greater insight into their own patterns of behavior and those of others, we contracted with the director of the local Jung Center to administer and explain the Myers-Briggs type indicator, which is based on Carl Jung's observation that measurable personality differences influence normal people's behavior. ${ }^{88}$ The multiple-choice questionnaire generates personal scoring profiles that reflect basic preferences on four scales: extroversion versus introversion; sensing versus intuition; thinking versus feeling; and judging versus perceiving. The theory holds that, in similar environments, persons of distinct types will behave differently in predictable ways.

88. See David Keirsey \& Marilyn Bates, Please Understand Me: Character \& TEMPERAMENT TYPES (1984); Richard Larry, The Lawyer Types-How Your Personality Affects Your Practice, 79 A.B.A. J. 74 (1993). 
The Myers-Briggs exercise reinforced systems theory by giving students a theoretical structure for analyzing different behaviors, not as shortcomings or error, but as a product of identifiable preferential patterns that are simply different. Classroom exercises illustrated how group interactions and decisions could be dramatically manipulated and predicted by changing the composition of personalities within a group. ${ }^{89}$ We used Myers-Briggs scores to assign class members to ten six-person core groups. The primary purpose of the groups was to provide a safe place for group members, but they were constituted with maximum variety so students could experience community with a wide range of personality types. With expectations that core groups would maintain their sense of community through the entire semester, our community consultant trained one volunteer in each group to keep groups on task and call attention to departures from community behavior. Through personal involvement, students learned that individuals function as systems within systems, and that we are both limited and empowered by our personal perspectives and preferences. ${ }^{90}$

5. Family of Origin Theory. Once we had established a functional level of community, we commenced family of origin theory and exercises. Electing to go to the heart of the value structure issue, we contracted with an accomplished family systems therapist, ${ }^{91}$ who agreed to explain family of origin theory and guide students through exercises leading toward preparing a "genogram," or family history. In an early class, the consultant displayed his own genogram, disclosing transgenerational patterns in his own life that commanded attention. It was a strong introduction, perhaps too strong. Some students felt ill at ease with this level of openness.

We received some of the strongest praise for community building and some of the sharpest criticism for the family of origin inquiry and exercises. Much of the criticism pointed to lack of initial clarity as to the purpose of family of origin segment and its connection with law practice. Some of the criticism simply identified the students' personal discomfort. The critical feedback was compelling enough to cause us to reassess our teaching methods, but not to discard the subject. A course in professional responsibility has to go beyond mere intellectual learning to be effective. The widespread public perception of many practicing lawyers as mean-spirited, relentless warriors who pursue victory and fees without any real concern for their own clients, much less others, and who are all too willing to make honesty and truth their first victims, is not

89. Thus ending, at least within the class, the myth of objectivity and rational maximizing.

90. Community building is not therapy. People reveal only what they choose to reveal, and they are not probed by a therapist. There is no requirement of closure on any issue. Some of our core groups chose to go deeply into their personal inquiries. For them, community building was seen as one of the most valuable aspects of the course. Others laughed their way through. For them, that process was either pointless or too threatening, and they dropped out. Both performed at an acceptable level-the level at which they felt comfortable.

91. Newton Hightower, Ph.D. 
without foundation. If these behaviors are rooted in family of origin principles, the theory must be addressed. However, we have been a little more cautious since the early criticism.

6. Student Involvement in Formulating Course Content. After the discussion of family of origin had put our students in a reflective frame of mind, we introduced a series of guests who told their stories. The students themselves played a major role in selecting the topics to be discussed. Professor Schuwerk provided the students with an extensive list of suitable topics. The students then selected the more limited number of topics they wished to explore in the time available. We drew on our knowledge of local attorneys, judges, and others to identify and solicit suitable candidates to serve as presenters of those issues. After the speakers were introduced and gave a brief personal statement, the students met in their core groups and formulated at least one question for each speaker. The group questions served as the basis for the subsequent discussions.

This format provided our students with an additional level of control over the course content. Having initially selected the broad area of inquiry, they now set more precise parameters for the actual discussion of that area. ${ }^{92}$ In a very real sense, the course was created by and belonged to the students taking it. They became invested in it to an extent, to hear them tell it, that far exceeded their commitment to other offerings.

7. Learning from Lawyers' Stories. Learning involves emotions, ${ }^{93}$ and the stronger the emotional connection, the greater the learning. While law students need to learn the written standards of their ethical landscape before they begin practice, we were hoping for more than cognition. We wanted to use knowledgeable and seasoned practitioners to communicate both the substance and the emotionality of their experiences, and so reach our students' spirit and soul. In essence, we wanted our classroom guests to serve as mentors for the entire class.

One fundamental rule guided our guests' visits to the classroom: No advance preparation! To ensure spontaneity, the guests used the ten questions formulated by the core groups to prompt their stories. Without much time to think about the questions, the guests had to be spontaneous. We urged our guests to tell their own experiences, exhibit their emotionality, express their personal responses and reflections on their own and other lawyers' behavior. For the last two months of the course, singly or in groups of two or three, some fifty invited guests-lawyers, judges, and a few other professionals-came to class and told their stories.

After one class meeting modeling the conversational format, the stories began. Students listened intently as well-known local practitioners and judges discussed their experiences with family stress, sexual discrimination, and

92. This device had the incidental benefit of preventing our guests from giving canned presentations of their favorite war stories.

93. HART, supra note 56, at 102. 
overbearing judges. Grievance officials and an attorney specializing in defending lawyers in disciplinary proceedings explained how attorneys run afoul of the disciplinary system. A pin-drop could have been heard when two disbarred lawyers discussed how they slipped into trouble. Three clients told of their satisfactions and frustrations with lawyers they had hired, covering matters ranging from unreturned phone calls to obviously inadequate representation. Later a lawyer specializing in legal malpractice painted an unfavorable picture of the grievance process and told stories about lawyers' abusive sexual involvement with clients.

Two solo practitioners, one from a small town and one from an urban area, described how to handle client funds and manage a law office to stay out of trouble and satisfy clients' needs. A managing partner described the economics of law practice and the reality of living on a lawyer's salary. Noted criminal lawyers role-played lawyer and client in interview vignettes designed to raise ethical issues that they discussed with the class. Tort lawyers, family lawyers, and mediators described their practices and recurring ethical problems.

A former state supreme court justice joined a panel to talk about professional courtesy. One member of that panel was an older African-American lawyer who told of his first-hand experiences as assistant U.S. attorney in the 1950s and 1960 s, when hotels revoked his room reservations and referred him to the "colored" motel across the tracks. Most of today's law students know racial segregation only as a history-book item, but they could feel this lawyer's pain as he described the events first-hand.

Near the end of the semester, we shifted to lawyers' lifestyles. Lawyers who despaired of practice told about pursuing alternative careers, from medicine to corporate practice to public service. Every student had to reflect on personal habits when lawyers told about drug and alcohol addiction that threatened or destroyed their careers. Students listened attentively as a consulting psychologist described how his lawyer patients handled and mishandled the stress of law practice, how it affected-and often destroyed-their family lives, and how they might guard against its bad effects.

One of the most rewarding comments came at the end of the course when, in a feedback session handled by a business management consultant, a class member said she had listened with dismay at how some lawyers act, but then she looked at her classmates and said she knew sixty people who would not act that way. The spontaneous class applause validated the semester.

8. Assessing The Course. Throughout the course, we solicited student feedback in a variety of forms. We met weekly with core group facilitators in the first six weeks of the course. ${ }^{94}$ After the first month's community-building activities, all of the students formally assessed the course's successes and failures. After the four family of origin sessions, we issued a separate

94. Class comments at our first meeting led us to alter the schedule. 
evaluation. The course's last scheduled class was led by a management consultant and was devoted entirely to structured feedback for improving the model. We also received valuable feedback from what we termed a class memorial, a book containing student essays of two types: first, a core group essay on improving the legal profession, and, second, each student's individual essay describing a positive insight from the course. ${ }^{95}$ Finally, in the Law Center's standard post-course evaluation, students ranked this offering 7 th out of 131 law courses offered that semester. The top 5 percent finish was a far cry from the traditional course's previous three-year average that, on the same scale, would place it in the bottom 5 percent of all law classes.

\section{Resources}

1. People. In addition to our own time commitments, we employed five paid consultants who provided indispensable ideas and classroom services. Phase one consultants-a practicing lawyer, a family of origin theorist, and a business management consultant-reviewed the proposed course format, brainstormed, and fine-tuned it. Phase two consultants-a community builder and clinical psychologist-participated in detailed planning and conducted all classes during the first month.

Although planning and implementing this course requires the involvement of persons with training and skills not normally found on a law school faculty that should not be a significant barrier to implementing the course in most settings. Law schools affiliated with universities should be able to find persons with the requisite expertise either among or through the faculties of colleges of business, education, psychology, or medicine. The schools not so affiliated should have no serious difficulties in locating equally proficient individuals in private practice, provided they are situated in an urban area.

2. Money. Expenses for developing and implementing the course were estimated at $\$ 16,000$ but actually amounted to roughly $\$ 13,000$ : $\$ 3,000$ for the systems seminar, travel, books, printing, and meals for lecturers and consultants; $\$ 2,000$ for pre-course planning consultants; $\$ 7,000$ for contract teachers' planning and classwork; ${ }^{96}$ and $\$ 1,000$, consisting primarily of out-of-pocket costs, for class guests' expenses. No lawyer or judge asked for or received an honorarium.

95. Each student received a copy of the book. We wanted to emphasize inspirational and positive thoughts, restricting negative comments to the regular class evaluation. To that extent, the personal essays are skewed, but judging from the absence of negative comments in the formal evaluations, they are not misleading.

96. This consists of the president of the local Jung Center, who administered and explained the Myers-Briggs type indicator, the management consultant who designed and taught in the first month of the course and handled the final feedback session, the consulting psychologist who developed and taught the materials on family of origin; and a psycologist who dealt with stress and burnout in the practice of law. 
Although we could have reduced costs by imposing on consultants with pleas to personal friendship and public service, we elected not to do so to reflect the real cost of replication, at our school and elsewhere. The costs of subsequent versions of the course have decreased substantially due to the elimination of much of the pre-course planning. The most recent version should cost approximately $\$ 6,000$.

\section{IV}

\section{What We Would Change}

Although the course was largely successful, some aspects worked better than others. Student feedback at the final class and our own observations generated several thoughts about changes for future offerings. ${ }^{97}$ Discussion of the course with attendees at the November 1995 Keck Foundation conference generated additional ideas.

\section{A. Time Allocation}

We needed more time to build community. The best possible schedule would devote a full day or two half-days to building community before the first regular class meeting, with classes thereafter meeting for two two-hour sessions per week. However, this solution is unworkable because of the difficulty of getting students to show up for a full day before the regular semester starts. The next best solution is to squeeze the process into two two-hour classes per week during the first month. Meeting class four hours per week is justifiable for a twoor three-credit course because of the reduced class preparation requirements.

Expanding class to two hours per meeting also makes the conversation classes work better. The storytelling format contemplated that students would spend five minutes in core groups formulating questions, then interact as an entire class with the guests, and retire to their core groups to discuss what they had heard. As it turned out, the three-part schedule was simply too ambitious for a ninety-minute class. Class conversations often ran too long to allow wrapup core group discussions, and there was no time left for group discussion or to review intellectual content from the assigned text.

Two-hour classes permit ten minutes for core groups to formulate questions for the guests, forty-five to fifty-minutes for class conversation, and a final

97. Students especially liked core group meetings, lack of grade competition, low stress, practical aspect of learning from lawyers, listening to disbarred attorneys, information about alternate careers, the Myers-Briggs exercise, learning about the grievance process, and the variety of speakers. They singled out the Covey book (THE 7 HABITS OF HIGHLY EFFECTIVE PEOPLE, supra note 55) and the Peck book (THE DIFFERENT DRUM, supra note 4) as especially useful. They preferred less role-playing and physical contact (some of the time-saving techniques used to create community); some wanted one or more extra classes to cover the disciplinary rules and other traditional law-of-lawyering materials, and to include more speakers on the "mental health" aspect of law practice and more disbarred attorney speakers. A substantial number of students felt the family of origin segment should either be made more clearly relevant or eliminated. 
thirty minute period for the core groups to process issues raised by the conversation. Professor Schuwerk is utilizing that format in the spring 1996 semester and has found it to be a considerable improvement.

\section{B. Rethinking Family of Origin}

Family of origin coverage was not entirely successful. We plunged students into confrontation with their family history without a clear explanation of its relevance. Some students were reluctant to discuss family history with other students, even in a protected environment, and we did not make it as clear as we should have that they could opt out. A few students viewed their families as ordinary, even dull, and felt challenged to come up with some artificial dirt to be "in," or resented having to search for defects. Some students came to appreciate the family of origin component only during the later part of the course. Others said it was useful to hear personal examples of transgenerational dysfunctional behavior.

To be more successful, the family of origin segment must present a stronger theoretical case for what it is and why it is important, signal what is coming through the exercises, and provide a structure that allows students to apply the theory to their own lives in an effective yet totally private way. In subsequent versions of the course, we have had our students delve more deeply into how their families of origin dealt with the important themes of denial, anger, and grief. Subsequent versions have also instituted a series of one-to-two page anonymous daily papers, in which students discuss law school or employment experiences that have caused them to experience denial, anger, or grief and how their families of origin affected the way in which they dealt with those experiences. The positive legacies of students' families and how students can draw on those resources in times of trouble is also emphasized more strongly. Professor Schuwerk has concluded each of these sessions with a short presentation tying the day's topic to ethical practice issues. This segment of the course is now much better received than it was originally.

\section{More Attention to the Law of Lawyering}

An important shortcoming of our initial course offering was that it did not do much with the formal rules and doctrines of the law of lawyering. Our focus on the course's more novel aspects led us to undervalue the importance of acquainting students with existing professional norms. In hindsight, while we believe the course as offered was a valuable experience, it should not have been allowed to satisfy our school's professional responsibility requirement on a stand-alone basis. We should have either required students to take a separate course or substantially increased the emphasis on the actual law of lawyering. Ignorance of the rules can be as destructive as a corrupt heart and mind. 
Students need to know the content of lawyer's rules and how they apply in paradigm situations. ${ }^{98}$

Our subsequent course offerings have addressed that body of law in an intellectually appropriate fashion while retaining the original overall pedagogy of the course. If the current incarnation is any example, students are even more enthusiastic about the new version than its predecessor, as it satisfies their desire to master the law of lawyering more completely. Under the current approach, Professor Schuwerk helps identify one or more ethical issues raised during the conversation hour and requires short, written, core group responses by the end of the class hour. He supplements those short assignments with nearly daily take-home essays requiring a more in-depth exploration of important ethical concerns raised in class and four to six longer essays based on a problem scenario. While Professor Schuwerk has evaluated these longer papers on a comparative basis, he has not done so using a curved letter grade system. We emphasize that it would not be proper to use graded exercises to reintroduce zero-sum, competitive classroom grading. Removing beggar-thy-neighbor competition from the course is essential to its success.

\section{Grading}

The plus and minus final grade uncurved grading system that we utilized, while eliminating destructive interpersonal competition, still carried an extrinsic aspect that proved moderately distracting. At the end of the course, students haggled for even higher grades. Frankly, we adopted the system in part as a "carrot" to ensure that a sufficient number of students signed up for the course. It turned out to be unnecessary for that purpose, and its non-competitive aspect can be attained in other ways. We have since abandoned it in favor of a pass/fail system, which appears to be working much better. ${ }^{99}$ Maintaining a high degree of student motivation and obtaining quality work have not been problems.

\section{V \\ CONCLUSION}

The course was fun to plan and execute. The results were rewarding beyond our most optimistic hopes. We accomplished most of our goals, and an overwhelming majority of students valued the course highly. Some of the feedback was touching. We may never know whether we had any long term effect, but surveys at one-year, three-year, and five-year intervals would be

98. Subsequent offerings of the course have spent considerably greater time on the applicable ethical standards. Key provisions are explored in depth through assigned papers.

99. A modified, less generous, uncurved letter-grade system was used in the second offering of the course and a pass/fail standard in the third, with "pass" set at the equivalent of a minimum of "C" or better on an uncurved letter-grade system. Each of these approaches has avoided the zero-sum competitive aspects of forced-curve grading, a feature we continue to view as essential to the course's success. 
useful. One thing is clear. A course that vaults from the bottom 5 percent to the top 5 percent in student acceptance is worth repeating for that reason alone.

There are, however, larger issues at stake. The underlying theories and research we relied upon, as well as our own observations of student behavior both in this course and elsewhere, apply with equal force to the entire law school curriculum, not just to law of lawyering offerings. The clear message is that pedagogical changes that alleviate student stress in law school and grading reforms that eliminate the forced curve will leave students far better off, both personally and professionally-in law school and quite probably thereafter as practitioners. Therefore, a reexamination of the principal methods of instruction and evaluation that have been used in most courses in most law schools for decades is in order.

Such assessment is long past due. However, a cautious, methodical approach must be taken. It would be prudent, for example, to attempt to replicate the underlying research on the effects of a legal education on the mental and emotional health of law students, both while they are in school and thereafter as lawyers. In order to test for hitherto unsuspected differential impacts, that research should be conducted in a variety of types of law schools and in a variety of instructional settings. ${ }^{100}$ Then, too, institutions considering implementing an uncurved or other (relatively) non-competitive grading system would be well advised to do so piecemeal. ${ }^{101}$ In that way, one could study the effects of the change on students' mental and emotional health, as well as on their motivation to excel and their mastery of course material, before making more widespread modifications. We hope that the Keck Foundation can play a pivotal role in this important undertaking.

100. It would not surprise us, for example, if the effects we have been discussing are more muted at national law schools, where the institution's prestige virtually guarantees worthwhile employment. We also speculate that a similar effect would occur wherever less competitive grading policies are utilized.

101. Perhaps a certain class of courses might be changed together. For example, we are considering whether to adopt an uncurved system for all lawyering process and lawyering skills courses, while leaving traditional academic courses and seminars untouched. 
